UDC 657.6:346.26

JEL Classification: M00

\title{
ANALYSIS OF THE CREDIT COMPONENT OF FINANCIAL SECURITY OF BUSINESS ENTITIES IN THE CONTEXT OF IMPROVING ACCOUNTING AND AUDITING
}

UDC 657.6:346.26

JEL Classification: MOO

\author{
๑ 2020 KRIVTSOVA T. O., LIADOVA Y. 0.
}

\author{
Krivtsova T. O., Liadova Y. O. \\ Analysis of the Credit Component of Financial Security of Business Entities \\ in the Context of Improving Accounting and Auditing
}

The aim of the article is to justify the ways to improve accounting and auditing. In view of this, the authors analyze the influence of factors of the internal and external environment, which are conditioned by the current global financial crisis, on the development of the credit component of financial security of enterprises. Using the methods of generalization, internal and external factors influencing the development of the credit component of financial security of enterprises are identified. The degree of liquidity of the assets of individual enterprises and the possibility of using the credit component in their activities are analyzed based on the calculation of their creditworthiness, solvency, financial stability, and financial status (factors of the internal environment).Bu means of econometric modeling, it is found that the development of the credit component of financial security of the studied business entities is slowed down due to excessive growth in their current liabilities, compared to the relatively moderate rate of changes in the volume of their assets, as well as the limited possibilities for long-term borrowing and low return on assets. The regression analysis of the impact made by fluctuations of the exchange rate of the domestic currency against the US dollar and the euro (environmental factor) on the development of the credit component of financial security of the studied business entities revealed that this factor negatively affects both the volume of credit resources and the business entity as a whole. Under modern conditions of the global financial crisis, the practical implementation of the research results will improve quality and speed of making managerial decisions, which are based on accounting and audit data. In this regard, it makes sense to direct further research at identifying and eliminating the consequences of the global financial crisis of 2020 in activities of business entities.

Keywords: accounting, audit, credit component, financial security, business entity, influence factors, credit resources

DOI: https://doi.org/10.32983/2222-0712-2020-2-256-264

Fig.: 1. Tabl.: 8. Bibl.: 10.

Krivtsova Tetiana 0. - Candidate of Sciences (Economics), Associate Professor, Associate Professor of the Department of Accounting and Business Consulting, Simon Kuznets Kharkiv National University of Economics (9a Nauky Ave., Kharkiv, 61166, Ukraine)

E-mail: krtatyana078@ukr.net

ORCID: http://orcid.org/0000-0002-1693-6781

Liadova Yuliia 0. - Candidate of Sciences (Economics), Associate Professor, Associate Professor of the Department of Accounting and Business Consulting, Simon Kuznets Kharkiv National University of Economics (9a Nauky Ave., Kharkiv, 61166, Ukraine)

E-mail: uliia.liadova@gmail.com

ORCID: http://orcid.org/0000-0002-7330-764X

УДК 657.6:346.26

JEL Classification: M00

Крівиова Т. О., Лядова Ю. О. Аналіз кредитної складової фінансового забезпечення суб'єктів підприємництва в контексті удосконалення обліку і аудиту

Метою цієї статті є обгрунтування шляхів удосконалення обліку і аудиту через аналіз впливу факторів внутрішнього та зовнішнього середовища на розвиток кредитної складової фінансового забезпечення суб'єктів підприємництва, що зумовлені сучасною світовою фінансовою кризою. За допомогою методів логічного узагальнення виокремлено внутрішні та зовнішні фактори впливу на розвиток кредитної складової фінансового забезпечення суб'єктів підприємництва. Проаналізовано рухомість власних фінансових ресурсів і можливість застосування кредитної складової у діяльності конкретного суб'єкта підприємництва на основі розрахунку показників кредитоспроможності, платоспроможності, фінансової стійкості та фінансового стану (фактори внутрішнього середовища). В результаті економетричного моделювання встановлено, що уповільнює розвиток кредитної складової фінансового забезпечення досліджуваних суб'єктів підприємництва надмірне зростання поточних зобов'язань порівняно
УДК 657.6:346.26

JEL Classification: MOO

Кривцова Т. А., Лядовая Ю. А. Анализ кредитной составляющей финансового обеспечения субъектов хозяйствования в контексте усовершенствования учета и аудита

Целью данной статьи является обоснование путей усовершенствования учета и аудита путем анализа влияния факторов внутренней и внешней среды на развитие кредитной составляющей финансового обеспечения субъектов хозяйствования, которые предопределены современным мировым финансовым кризисом. С помощью методов логического обобщения выделены внутренние и внешние факторы влияния на развитие кредитной составляющей финансового обеспечения субъектов хозяйствования. Проанализированы подвижная способность собственных финансовых ресурсов и возможность применения кредитной составляющей в деятельности конкретного субъекта хозяйствования на основе расчета показателей кредитоспособности, платежеспособности, финансовой стойкости и финансового состояния (факторы внутренней среды). Путём эконометрического моделирования выявлено: развитие кредитной составляющей финансового обеспечения исследуемых субъектов хозяйствования замедляет избы- 
з відносно помірною динамікою зміни обсягів їх активів, а також обмежені можливості довгострокового залучення запозичених ресурсів та низька окупність їх активів. Регресійний аналіз впливу коливань курсу національної грошової одиниці відносно до долара США та євро (фактор зовнішнього середовища) на розвиток кредитної складової фінансового забезпечення досліджуваних суб'єктів підприємництва дозволив встановити, що такий фактор негативно впливає як на обсяги залучення кредитних ресурсів, так і на діяльність суб'єкта підприємництва в цілому. Практична реалізація результатів дослідження дозволить підвищити якість і швидкість прийняття управлінських рішень, які базуються на даних обліку і аудиту в сучасних умовах світової фінансової кризи. Узз'язку з цим подальші розробки має сенс зосередити на виявленні й усуненні наслідків світової фінансової кризи 2020 р. в діяльності суб'єктів підприємництва.

Ключові слова: облік, аудит, кредитна складова, фінансове забезпечення, суб'єкт підприємництва, фактори впливу, кредитні ресурси.

Рис.: 1. Табл.: 8. Бібл.: 10.

Крівцова Тетяна Олександрівна-кандидат економічних наук, доцент, доцент кафедри обліку і бізнес-консалтингу, Харківський національний економічний університет ім. С. Кузнеця (просп. Науки, 9а, Харків, 61166, Україна)

E-mail: krtatyana078@ukr.net

ORCID: http://orcid.org/0000-0002-1693-6781

Лядова Юлія Олександрівна - кандидат економічних наук, доцент, дочент кафедри обліку і бізнес-консалтингу, Харківський національний економічний університет ім. С. Кузнеця (просп. Науки, 9а, Харків, 61166, Україна)

E-mail: uliia.liadova@gmail.com

ORCID: http://orcid.org/0000-0002-7330-764X точный рост текущих обязательств по сравнению с относительно умеренной динамикой изменения объемов их активов, а также ограниченные возможности долгосрочного привлечения заимствованных ресурсов и низкая окупаемость их активов. Регрессионный анализ влияния колебаний курса национальной денежной единицы относительно доллара США и евро (фактор внешней среды) на развитие кредитной составляющей финансового обеспечения исследуемых субъектов хозяйствования позволил установить, что такой фактор негативно влияет как на объемы привлечения кредитных ресурсов, так и на деятельность субъекта хозяйствования в целом. Практическая реализация результатов исследования позволит повысить качество и скорость принятия управленческих решений, которые базируются на данных учета и аудита в современных условиях мирового финансового кризиса. В связи с этим последующие разработки имеет смысл направить на выявление и устранение последствий мирового финансового кризиса 2020 г. в деятельности субъектов хозяйствования.

Ключевые слова: учет, аудит, кредитная составляющая, финансовое обеспечение, субъект хозяйствования, факторы влияния, кредитные ресурсы.

Рис.: 1. Табл.: 8. Библ.: 10.

Кривцова Татьяна Александровна-кандидат экономических наук, доцент, доцент кафедры учета и бизнес-консалтинга, Харьковский национальный экономический университет им. С. Кузнеца (просп. Науки, 9а, Харьков, 61166, Украина)

E-mail: krtatyana078@ukr.net

ORCID: http://orcid.org/0000-0002-1693-6781

Лядовая Юлия Александровна - кандидат экономических наук, доцент, доцент кафедры учета и бизнес-консалтинга, Харьковский национальный экономический университет им. С. Кузнеца (просп. Науки, 9а, Харьков, 61166, Украина)

E-mail: uliia.liadova@gmail.com

ORCID: http://orcid.org/0000-0002-7330-764X
Introduction. Despite the rapid reforming of the financial control system in Ukraine, auditing, as an entrepreneurial activity, requires immediate changes in the provision of audit services. Indeed, competition among supervisory bodies is increasing, the powers of public financial control bodies are expanding, and the financial control system is acquiring European features. Therefore, it is advisable to expand audit activities by applying new technologies in the auditing practice to carry out audit procedures, in particular those relating to improving financial security of enterprises by attracting credit resources. In addition, issues of ensuring credit support for enterprises are of particular importance during a downturn. Under conditions of the global crisis caused by the Covid-2019 virus, the Ukrainian economy as a whole and the financial system in particular is suffering significant losses. There is a sharp decline in GDP, which is a consequence of the reduction in production; increase in consumer prices; decrease in stock indices; some investors are forced to withdraw their capital from developing countries. However, in this situation, Ukraine still has opportunities for transformations in order to overcome the crisis with minimal losses and continue development.

Important in this context is the search for the most acceptable and real ways of development in the sectors of small, medium-sized and large enterprises, in particular, improvement of the financial security of Ukrainian enterprises. One of the key components of financial security of enterprises is the credit component (especially bank crediting). The state and development of the credit component of financial security of enterprises are significantly affected by factors of the external and internal environment. It is possible to assess this impact by analyzing reliable accounting data, statistical, production and other background information used to make management decisions in banks and enterprises.

Among researches of Ukrainian and foreign academic economists, special attention should be paid to works of R. A. Brealey, P. Yu. Buryak, L. V. Dikan, S. V. Levochkin, K. K. Seo, O. O. Tereshchenko, which deal with problems of financial security of business entities, as well as those of G. M. Azarenkova, O. I. Baranovskyi, L. V. Rudenko, who investigated the issue of credit support for activities of enterprises. Regarding the definition of areas for analyzing and justifying certain internal aspects of financial status and development of financial security of enterprises including bank crediting, it is advisable to consider works of O. O. Tereshchenko, where financial aspects of crisis management are considered with consideration for enterprise financial stability and financial status [1]; G. M. Azarenkova, where a set of indicators of creditworthiness and financial status of an enterprise as 
a generalization of factors of the internal environment in relation to its financial security is determined [2]; P. Yu. Buryak, who summarizes the development of financial security in terms of such internal factors as the ability of enterprises to fulfill their obligations on credits granted in terms of efficiency of using their own funds and impact of the amount of profit on changes in the volume of their equity [3]; B. V. Samorodov, who determines stability of the bank crediting process on the basis of measuring stability of time series according to the FosterStewart round-trip criterion, which allows a comprehensive analysis of stability of banking institutions and timely respond to globalization and internal challenges [4].

At the same time, a number of issues related to accounting and auditing the state of financial security of enterprises require further analysis and improvement, which determined the relevance of the research topic and its purpose.

The aim of the article is to justify the ways to improve accounting and auditing through analyzing the influence of factors of the internal and external environment on the development of the credit component of financial security of enterprises, caused by the current global financial crisis.

Results. It is advisable to start considering this influence with factors of the internal environment. The changes in the credit component of the financial security of an enterprise are largely determined by its activities. Therefore, the issue of considering factors of influence on the development of the credit component of financial security of an enterprise is directly interconnected with its functioning. Based on the fact that the subject of the study is the credit component of financial security, the consideration of the functioning of a business entity should be carried out in view of the possibility of attracting additional resources through crediting. This means that the effectiveness of influence factors in terms of the development of the credit component of financial security of enterprises is, first of all, generalized due to the possibility of using the credit component in activities of a particular business entity. This possibility is determined on the basis of analysis of the totality of indicators: creditworthiness, solvency, financial stability and financial status of the enterprise. Thus, the definition of factors of the internal environment influencing the development of the credit component of financial security of a business entity is determined by the ability of the business entity to fulfill its obligations for servicing credit resources, efficiency of its gaining profit from assets, structure of the capital employed to finance the enterprise's activities, effectiveness of using its own funds, etc.

However, given the subject of this study, it is necessary to analyze the performance indicators of enterprises that determine factors influencing the development of the credit component of their financial security in terms of the possibility of using credit resources. First of all, this possibility is assessed based on liquidity indicators, which reflect the ability of a business entity to fulfill its short-term obligations. This means to fulfill the current obligations of the business entity, which from the point of view of credit resources can be defined as the ability to pay interest on resources received and gradually repay the bank the principal.

In general, there distinguished absolute, quick and current liquidity indicators, which differ from each other in that part of the assets that can cover the current liabilities. Among these indicators, the current ratio, which is calculated as the ratio of current assets of the enterprise to its current liabilities, can be considered the summarizing one [5]. Therefore, theoretically, the value of this indicator should not be less than one.

The study uses accounting and statistical data on the studied enterprises in the Eastern region for 2013-2019 from the website of Stock Market Infrastructure Development Agency of Ukraine (SMIDA) [6]. The representativeness of the sample is confirmed by the following: all enterprises belong to medium and large enterprises, according to Art. 55 of the Commercial Code of Ukraine; carry out activities in the engineering industry. Table 1 shows the values of the current ratio for the studied enterprises.

From the data of Table 1 it can be seen that the value of the current ratio for almost all the studied enterprises, with the exception of PrJSC "KhTZ", is higher than 1. It should also

Table 1

Current ratio

\begin{tabular}{|l|c|c|c|c|c|c|c|}
\hline \multirow{2}{*}{ Enterprise } & \multicolumn{9}{c|}{ Year } \\
\cline { 2 - 9 } & $\mathbf{2 0 1 3}$ & $\mathbf{2 0 1 4}$ & $\mathbf{2 0 1 5}$ & $\mathbf{2 0 1 6}$ & $\mathbf{2 0 1 7}$ & $\mathbf{2 0 1 8}$ & $\mathbf{2 0 1 9}$ \\
\hline PrJSC Kharkiv Bearing Plant & 3.70 & 3.71 & 4.89 & 3.39 & 5.30 & 4.45 & 3.00 \\
\hline PrJSC «KhTZ» & 1.77 & 1.59 & 2.13 & 1.68 & 1.30 & 0.96 & 0.83 \\
\hline PrJSC «Kharkiv Machine-Tool Plant» & 2.76 & 2.48 & 3.25 & 2.72 & 2.99 & 1.78 & 1.46 \\
\hline Luhanskteplovoz PJSC & 1.84 & 1.90 & 1.87 & 2.58 & 1.43 & 1.19 & 1.07 \\
\hline PrJSC «AutoKrAZ» & 2.45 & 3.06 & 4.29 & 2.12 & 2.07 & 1.99 & 1.61 \\
\hline Dniprovagonmash PrJSC & 1.88 & 1.61 & 1.69 & 1.54 & 3.09 & 1.74 & 1.36 \\
\hline Kyivpoligraphmash PrJSC & 2.13 & 6.48 & 7.00 & 8.85 & 2.35 & 2.68 & 3.58 \\
\hline PJSC «HMZ» & 3.93 & 3.25 & 5.19 & 6.17 & 9.54 & 4.73 & 2.95 \\
\hline $\begin{array}{l}\text { PJSC «Artyomovsk Machine Building Factory } \\
\text { «Pobeda Truda» }\end{array}$ & 51.56 & 6.41 & 5.99 & 3.53 & 2.02 & 2.28 & 1.80 \\
\hline PrJSC «Kupyansk machine-building plant» & 246.48 & 146.30 & 39.98 & 41.11 & 32.81 & 10.76 & 2.57 \\
\hline
\end{tabular}

Source: developed by the authors based on [6] 
be noted that within the considered time period, none of the enterprises demonstrated a steady upward trend in terms of the ratio. Moreover, starting from 2017, the current ratio of a significant part of the studied enterprises decreases over time. In particular, for PrJSC "KhTZ", the drop in the current ratio resulted in a sharp decrease in the volume of borrowings, which does not contribute to the development of the credit component of financial security of this enterprise (Tbl. 2). Table 2 shows the changes in the volume of credits granted to the enterprises under study.

Table 2

Total amount of credits received by the studied enterprises

\begin{tabular}{|l|c|c|c|c|c|c|c|}
\hline \multirow{2}{*}{ Enterprises } & \multicolumn{9}{c|}{ Year, ths. hrn. } \\
\cline { 2 - 9 } & $\mathbf{2 0 1 3}$ & $\mathbf{2 0 1 4}$ & $\mathbf{2 0 1 5}$ & $\mathbf{2 0 1 6}$ & $\mathbf{2 0 1 7}$ & $\mathbf{2 0 1 8}$ & $\mathbf{2 0 1 9}$ \\
\hline PrJSC Kharkiv Bearing Plant & 7500 & 19898.6 & 17304.7 & 28191.3 & 44553.2 & 92259 & 104397 \\
\hline PrJSC «KhTZ» & 72999.6 & 78400.3 & 176622.9 & 124641.4 & 12577.5 & 13727 & 12347 \\
\hline PrJSC «Kharkiv Machine-Tool Plant» & 1749.5 & 3593.3 & 3787.5 & 6827.2 & 6312.5 & 0 & 11690 \\
\hline Luhanskteplovoz PJSC & 45157 & 47794 & 78661 & 98776 & 50460 & 62116 & 0 \\
\hline PrJSC «AutoKrAZ» & 93474.4 & 111460.1 & 161269.7 & 75641.8 & 62793.9 & 1291544 & 1393441 \\
\hline Dniprovagonmash PrJSC & 20265 & 87286.8 & 101884.3 & 189719.1 & 82536.5 & 276050 & 252056 \\
\hline Kyivpoligraphmash PrJSC & 470 & 0 & 0 & 0 & 0 & 0 & 0 \\
\hline PJSC «HMZ» & 0 & 0 & 0 & 0 & 0 & 0 & 0 \\
\hline $\begin{array}{l}\text { PJSC «Artyomovsk Machine } \\
\text { Building Factory «Pobeda Truda» }\end{array}$ & 147.7 & 71.5 & 0 & 0 & 0 & 0 & 0 \\
\hline $\begin{array}{l}\text { PrJSC «Kupyansk machine-building } \\
\text { plant» }\end{array}$ & 0 & 0 & 0 & 0 & 0 & 0 & 0 \\
\hline
\end{tabular}

Source: developed by the authors based on [6]

At the same time, according to the results of the considered time period, it can be noted that a significant drop in the current liquidity ratio of PrJSC "Kharkiv Machine-Tool Plant" during 2018-2019 also affected the total amount of borrowings. It is the critical value of the current ratio for Luhanskteplovoz PJSC at the end of 2019 that affected the volumes of borrowings during this period.

Thus, one of the factors hindering the development of the credit component of financial security of the studied enterprises is an excessive increase in their current liabilities compared to the relatively moderate changes in the volume of the assets, for some enterprises (Luhanskteplovoz PJSC, Dniprovagonmash $\mathrm{Pr}$ (SC) being even decreasing. It is this that ultimately affects the presented in Table 1 changes in the values of the current ratio for the mentioned enterprises.

It is worth noting that Kyivpoligraphmash PrJSC, PJSC "HMZ", PJSC "Artyomovsk Machine Building Factory "Pobeda Truda" and PrJSC "Kupyansk machine-building plant" prefer other resources to the credit component of their financial security. This conclusion is based on the comparison of the data in Table 1 and Table 2 with the values of payables for goods, works, services, depreciation and equity for the relevant periods. However, a gradual decrease in the equity of PJSC "HMZ", PJSC "Artyomovsk Machine Building Factory "Pobeda Truda", PrJSC "Kupyansk machine-building plant" and the need to reduce payables, at least for PJSC "HMZ", PJSC "Artyomovsk Machine Building Factory "Pobeda Truda", will contribute to the development of the credit component of their financial security. Thus, the justification of the issue of attracting credit resources on a step-by-step basis is relevant. However, the issue is rather closely related to determining the ability of enter- prises to receive long-term borrowings. Thus, it is advisable to generalize and consider this possibility in view of the studied enterprises.

Table 3 presents the values of long-term debt ratio, which is defined as the ratio of long-term liabilities to the sum of long-term liabilities and equity, which allows characterizing the capital structure [5]. Therefore, the growth of this ratio indicates a growing dependence on external investors.

The comparison of the data in Table 3 with the data in Table 2 showed that the negative trend in changes of the longterm debt ratio (i.e., its growth) is characteristic only to those enterprises that demonstrate constant volumes of increase in the credit component of their financial security, the exception being Dniprovagonmash PrJSC.

The rest of the studied enterprises, namely Kyivpoligraphmash PrJSC, PJSC "HMZ", PJSC "Artyomovsk Machine Building Factory "Pobeda Truda" and PrJSC "Kupyansk machine-building plant" have either zero values of long-term debt ratio (i.e., they have practically no long-term obligations), or the value of the ratio is characterized by a downward trend.

For the purpose of a more detailed study of those enterprises for which the values of the long-term debt ratio are determined (PrJSC Kharkiv Bearing Plant, PrJSC "KhTZ", PrJSC "Kharkiv Machine-Tool Plant", Luhanskteplovoz PJSC, PrJSC "AutoKrAZ", Dniprovagonmash PrJSC), the analysis of the correlation of these values with the changes in the volumes of credits granted is carried out (Fig. 1 and Tbl. 3).

For PrJSC Kharkiv Bearing Plant, an increase in the long-term debt ratio is taking place against the background of an increase in the volume of credits granted, which is the evidence of the need to take into account the prevalence of 
Long-term debt ratio

\begin{tabular}{|l|l|l|l|l|l|l|l|}
\hline \multirow{2}{*}{ Enterprise } & \multicolumn{3}{c|}{ Year } \\
\cline { 2 - 9 } & $\mathbf{2 0 1 3}$ & $\mathbf{2 0 1 4}$ & $\mathbf{2 0 1 5}$ & $\mathbf{2 0 1 6}$ & $\mathbf{2 0 1 7}$ & $\mathbf{2 0 1 8}$ & $\mathbf{2 0 1 9}$ \\
\hline PrJSC Kharkiv Bearing Plant & 0.28 & 0.48 & 0.49 & 0.55 & 0.67 & 0.75 & 0.67 \\
\hline PrJSC «KhTZ» & 0.10 & 0.16 & 0.56 & 0.49 & 0.88 & -3.94 & -0.81 \\
\hline PrJSC «Kharkiv Machine-Tool Plant» & 0.01 & 0.06 & 0.19 & 0.26 & 0.37 & 0.39 & 0.43 \\
\hline Luhanskteplovoz PJSC & 0.02 & 0.15 & 0.21 & 0.35 & 0.21 & 0.21 & 1.71 \\
\hline PrJSC «AutoKrAZ» & 0.01 & 0.02 & 0.02 & 0.05 & 0.08 & 0.40 & 0.33 \\
\hline Dniprovagonmash PrJSC & 0.08 & 0.05 & 0.00 & 0.01 & 0.01 & 0.02 & 0.01 \\
\hline Kyivpoligraphmash PrJSC & 0.03 & 0.00 & 0.00 & 0.00 & 0.00 & 0.00 & 0.00 \\
\hline PJSC «HMZ» & 0.02 & 0.01 & 0.01 & 0.01 & 0.01 & 0.01 & 0.01 \\
\hline $\begin{array}{l}\text { PJSC «Artyomovsk Machine Building Factory } \\
\text { «Pobeda Truda» }\end{array}$ & 0.00 & 0.00 & 0.00 & 0.00 & 0.00 & 0.00 & 0.00 \\
\hline PrJSC «Kupyansk machine-building plant» & 0.01 & 0.00 & 0.00 & 0.00 & 0.00 & 0.00 & 0.00 \\
\hline
\end{tabular}

Source: developed by the authors based on [6]

long-term borrowings in order to prevent excessive growth of this ratio and improve the long-term borrowing potential of this company. The changes in the values of the considered indicators for PrJSC "AutoKrAZ" is approximately the same. However, PrJSC "AutoKrAZ" demonstrates a more positive trend since a significant increase in the values of the long-term debt ratio is observed only in 2018-2019.
For PJSC KhTZ and PJSC Kharkiv Machine-Tool Plant, the correlation between the values of long-term debt ratio and the volume of credits granted is moderate. However, at the same time, a decrease in the total amount of borrowed resources and an increase in the long-term debt ratio is observed, which generally reduces the possibility of long-term borrowing by these enterprises.

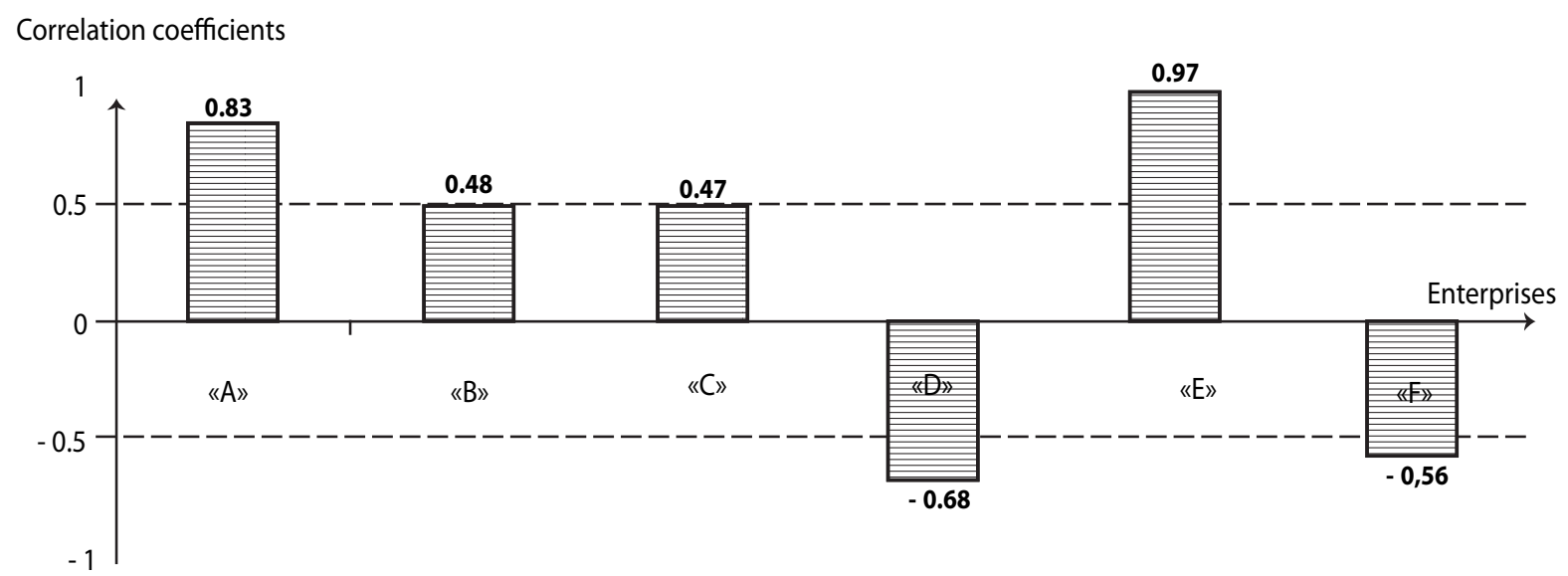

«A» - PrJSC Kharkiv Bearing Plant; «B» - PrJSC «KhTZ»; «C » - PrJSC «Kharkiv Machine-Tool Plant»;

«D» - Luhanskteplovoz PJSC; «E - PrJSC «AutoKrAZ»; «F» - Dniprovagonmash PrJSC

Figure 1. Correlation between the value of the long-term debt ratio and the volume of credits for the studied enterprises

Source: developed by the authors based on [6]

Luhanskteplovoz PJSC has a negative correlation between the values of the long-term debt ratio and the volume of credits granted. A detailed review of this value indicates the negative trend of increasing the long-term debt ratio of Luhanskteplovoz PJSC because the increase occurs against the background of a decrease in the volume of borrowings, at least since 2016 (Tbl. 2).

The value of the correlation between the values of the longterm debt ratio and the volume of credits for Dniprovagonmash $\mathrm{PrJSC}$ is also negative. However, this negative value indicates a decrease in the long-term debt ratio against the background of an increase in the volume of credits.

Therefore, summing up, it can be noted that the development of the credit component of financial security is to some extent hindered by possibilities of long-term borrowing from the point of view of the existing trends in corresponding statistical data for the enterprises studied.

Therefore, the issue of determining the financial dependence of the studied enterprises is relevant. It can be considered on the basis of generalization of the leverage ratio, 
which is calculated as the ratio of the volume of long-term and current liabilities and the volume of equity [7]. Thus, in the end, this ratio shows the share of borrowings per one hryvnia of the borrower's own funds. Theoretically, the values of this ration should be no more than 1 [7]. Table 4 presents the values of the leverage ratio for the studied enterprises.

Table 4

Leverage ratio

\begin{tabular}{|l|c|c|c|c|c|c|c|}
\hline \multirow{2}{*}{\multicolumn{1}{c|}{ Enterprise }} & \multicolumn{9}{c}{ Year } \\
\cline { 2 - 9 } & $\mathbf{2 0 1 3}$ & $\mathbf{2 0 1 4}$ & $\mathbf{2 0 1 5}$ & $\mathbf{2 0 1 6}$ & $\mathbf{2 0 1 7}$ & $\mathbf{2 0 1 8}$ & $\mathbf{2 0 1 9}$ \\
\hline PrJSC Kharkiv Bearing Plant & 0.97 & 1.63 & 1.46 & 2.12 & 2.69 & 4.10 & 3.54 \\
\hline PrJSC «KhTZ» & 1.57 & 2.21 & 3.30 & 3.83 & 34.70 & -6.40 & -3.71 \\
\hline PrJSC «Kharkiv Machine-Tool Plant» & 0.58 & 0.75 & 0.76 & 1.13 & 1.39 & 2.71 & 4.56 \\
\hline Luhanskteplovoz PJSC & 1.26 & 1.49 & 1.77 & 1.52 & 3.33 & 4.14 & -28.08 \\
\hline PrJSC «AutoKrAZW & 1.14 & 0.66 & 0.38 & 1.07 & 1.11 & 2.38 & 2.98 \\
\hline Dniprovagonmash PrJSC & 1.28 & 1.74 & 1.43 & 1.94 & 0.49 & 1.41 & 2.85 \\
\hline Kyivpoligraphmash PrJSC & 0.93 & 0.18 & 0.17 & 0.13 & 0.74 & 0.59 & 0.39 \\
\hline PJSC «HMZ» & 0.37 & 0.46 & 0.25 & 0.20 & 0.13 & 0.29 & 0.54 \\
\hline $\begin{array}{l}\text { PJSC «Artyomovsk Machine Building Factory } \\
\text { «Pobeda Truda» }\end{array}$ & 0.02 & 0.19 & 0.20 & 0.39 & 0.98 & 0.78 & 1.25 \\
\hline PrJSC «Kupyansk machine-building plant»- & 0.01 & 0.01 & 0.03 & 0.02 & 0.03 & 0.10 & 0.64 \\
\hline
\end{tabular}

Source: developed by the authors based on [6]

As can be seen from the data in Table 4, all of the studied enterprises that continuously attract credit resources demonstrate a growth in the values of the leverage ratio. At the same time, those enterprises that have a moderate increase in the value of this ratio (and these are, first of all, PrJSC "AutoKrAZ" and Dniprovagonmash PrJSC), according to the results of the considered time period, demonstrate a relatively steady increase in the volume of borrowings.

In contrast, Kyivpoligraphmash PrJSC, PJSC "HMZ", PJSC "Artyomovsk Machine Building Factory "Pobeda Truda" and PrJSC "Kupyansk machine-building plant" have moderate values of the leverage ratio, due to the fact that these enterprises give preference to others components of their financial security.
Therefore, to determine the effects of the structure of borrowed and own funds on the development of the credit component of the financial security of enterprises, it is also necessary to consider the current assets to equity ratio of the studied enterprises, which is defined as the ratio of the difference between the total equity and non-current assets to the total equity. The optimal theoretical value of this ratio should be not less than 0.5 [7].

Table 5 presents the values of the current assets to equity ratio for the studied enterprises.

As can be seen from Table 5, most of the studied enterprises have unsatisfactory values and changes in the current assets to equity ratio. In particular, this can explain the

Table 5

Current assets to equity ratio

\begin{tabular}{|l|c|c|c|c|c|c|c|}
\hline \multirow{2}{*}{ Enterprise } & \multicolumn{9}{c|}{ Year } \\
\cline { 2 - 9 } & $\mathbf{2 0 1 3}$ & $\mathbf{2 0 1 4}$ & $\mathbf{2 0 1 5}$ & $\mathbf{2 0 1 6}$ & $\mathbf{2 0 1 7}$ & $\mathbf{2 0 1 8}$ & $\mathbf{2 0 1 9}$ \\
\hline PrJSC Kharkiv Bearing Plant & 0.12 & -0.23 & -0.39 & -0.72 & -1.00 & -1.23 & -1.00 \\
\hline PrJSC «KhTZ» & -0.56 & -0.79 & -0.95 & -1.43 & -14.41 & 3.39 & 2.66 \\
\hline PrJSC «Kharkiv Machine-Tool Plant» & 0.37 & 0.33 & 0.30 & 0.15 & 0.15 & 0.38 & -0.10 \\
\hline Luhanskteplovoz PJSC & -0.14 & -0.20 & -0.20 & -0.15 & -0.50 & -0.39 & 12.54 \\
\hline PrJSC «AutoKrAZ» & 0.30 & 0.00 & -0.07 & -0.01 & -0.06 & -0.26 & -0.11 \\
\hline Dniprovagonmash PrJSC & 0.60 & 0.57 & 0.51 & 0.52 & 0.75 & 0.81 & 0.61 \\
\hline Kyivpoligraphmash PrJSC & -0.10 & 0.62 & 0.65 & 0.56 & 0.49 & 0.45 & 0.57 \\
\hline PJSC «HMZ» & 0.61 & 0.66 & 0.67 & 0.66 & 0.64 & 0.63 & 0.64 \\
\hline $\begin{array}{l}\text { PJSC «Artyomovsk Machine Building Factory } \\
\text { «Pobeda Truda» }\end{array}$ & 0.04 & -0.01 & -0.04 & 0.68 & 0.67 & 0.66 & 0.60 \\
\hline PrJSC «Kupyansk machine-building plant» & 0.17 & 0.16 & 0.13 & 0.12 & 0.12 & 0.06 & 0.08 \\
\hline
\end{tabular}

Source: developed by the authors based on [6] 
insufficient development of the credit component of financial security of PrJSC "Kupyansk machine-building plant".

Along with this, the changes in the values of the current assets to equity ratio of Dniprovagonmash PrJSC contribute to an increase in the volume of borrowings (the data in Table 2 and Table 5 in comparison).

Therefore, in general, according to Table 5, we can conclude that the factor that negatively influences the current assets to equity ratio of the studied enterprises, and, consequently, the development of the credit component of their financial security, may be the changes in the volume of assets of enterprises, which reflect investments capitalized in assets. Therefore, it is also worth considering the return on assets of the studied enterprises.

Table 6 shows the values of the return on assets, which indicates the effectiveness of making a profit using assets and is calculated as the ratio of net income after tax to total assets [7].

Thus, in a theoretical sense, the value of the return on assets should be positive and tend to grow.

Table 6

Return on assets

\begin{tabular}{|l|c|c|c|c|c|c|c|}
\hline \multirow{2}{*}{ Enterprise } & \multicolumn{7}{c|}{ Year } \\
\cline { 2 - 8 } & $\mathbf{2 0 1 3}$ & $\mathbf{2 0 1 4}$ & $\mathbf{2 0 1 5}$ & $\mathbf{2 0 1 6}$ & $\mathbf{2 0 1 7}$ & $\mathbf{2 0 1 8}$ & $\mathbf{2 0 1 9}$ \\
\hline PrJSC Kharkiv Bearing Plant & -0.0097 & 0.0609 & 0.0044 & -0.0425 & -0.0110 & -0.0138 & 0.0556 \\
\hline PrJSC «KhTZ» & -0.1476 & -0.1032 & -0.0378 & -0.0591 & -0.1238 & -0.2147 & -0.1623 \\
\hline PrJSC «Kharkiv Machine-Tool Plant» & -0.0156 & -0.0321 & -0.0568 & -0.0019 & 0.0008 & -0.1543 & -0.1384 \\
\hline Luhanskteplovoz PJSC & -0.0240 & 0.0005 & -0.0011 & -0.0397 & -0.0240 & 0.0017 & -0.3572 \\
\hline PrJSC «AutoKrAZ» & 0.0011 & 0.0364 & 0.0407 & 0.0204 & 0.0177 & 0.0072 & 0.0055 \\
\hline Dniprovagonmash PrJSC & 0.0026 & -0.0290 & -0.0031 & 0.0367 & 0.3188 & 0.2441 & -0.2552 \\
\hline Kyivpoligraphmash PrJSC & 0.0743 & 0.0990 & -0.1339 & -0.0121 & 0.6918 & -0.1133 & 0.1185 \\
\hline PJSC «HMZ» & -0.0549 & -0.0284 & 0.0017 & 0.0009 & -0.0531 & -0.0124 & -0.0302 \\
\hline $\begin{array}{l}\text { PJSC «Artyomovsk Machine Building } \\
\text { Factory «Pobeda Truda» }\end{array}$ & -0.0513 & -0.0484 & -0.0305 & -0.1226 & -0.0465 & -0.0459 & -0.0958 \\
\hline PrJSC «Kupyansk machine-building plantA & -0.0093 & -0.0264 & -0.0555 & -0.0337 & -0.0312 & -0.0799 & -0.1632 \\
\hline
\end{tabular}

Source: developed by the authors based on [6]

As can be seen from the data in Table 6, one of the main reasons for the insufficient development of the credit component of the financial security of the studied enterprises is a low return on assets. For example, PJSC "Artyomovsk Machine Building Factory "Pobeda Truda, PrJSC "Kupyansk machinebuilding plant", and PrJSC "KhTZ" are characterized by negative values of the return on assets over the entire period considered.

PrJSC "AutoKrAZ" is characterized by positive values of the return on assets over the entire studied period, but these values do not show a clear upward trend. The rest of the studied enterprises have both positive and negative values of the return on assets during the considered period.

Therefore, as a result, we can conclude that the return on assets is one of the significant factors hindering the development of the credit component of the financial security of the studied enterprises. However, the slowdown is not conditioned solely by factors of the internal environment.

It should be noted that from the position of the bank, it is also important to consider the indicators of financial stability of borrowing enterprises. In particular, according to the Regulation for Measuring Credit Risk Generated by Banks' Asset Operations [8], in order to calculate credit loss provisions and determine the credit risk, the bank must evaluate the financial status of the borrower based on certain economic indicators including solvency, financial stability, profitability, etc. Depending on the quantitative values of these indicators, en- terprises can be divided into classes from the standpoint of the reliability of credit repayment. So, according to the calculations presented in Table 1 and Table 4, banks can evaluate the ability of borrowers to repay credits.

External factors, the number of which is also considerable, also have a significant impact on the analyzed development process of the credit component of financial security. These are inflationary factors, price aspects of resources required for the operation of industrial enterprises, investment climate, tax burden, terms of credit, level of development of the financial sector of the economy, etc. [9]. Taking into account the global financial crisis, let us consider in more detail the influence of fluctuations in the exchange rate of the domestic currency on steady development of the credit component of financial security of enterprises. The result of its effect can be determined using regression analysis. At the same time, in the course of the analysis, it is necessary to evaluate 1 ) the influence of fluctuations of exchange rate of the domestic currency on the changes in the volume of credits granted; 2) the influence of these fluctuations, together with the changes in the volume of credits granted, on the changes in the volume of income received from the sale of finished products for those enterprises that have stable volumes of borrowings within the considered time period.

In the first of the abovementioned cases, the influence of exchange rate fluctuations on the volume of borrowings is clarified, and in the second, the effect of the volumes of credits 
granted on the changes in the volumes of income received from the sale of finished products, with regard to the possible credit currency, is determined.

Fluctuations of the domestic currency exchange rate are worth considering in terms of fluctuations of the value of the domestic currency against the US dollar and the euro. For calculations, the official exchange rate of hryvnia to foreign currencies, established by the National Bank of Ukraine, was used, the average for the considered period [10]. Table 7 presents the regression equations with normal coefficients at independent variables for the influence of fluctuations of the exchange rate of the domestic currency against the US dollar and the euro on the changes in the volume of credits granted for a number of studied enterprises.

Table 7

Regression equations to determine the influence of fluctuations of the domestic currency against the US dollar (VDC) and the euro (VEV) on the changes in the volume of credits granted (KR) for the studied enterprises

\begin{tabular}{|l|l|}
\hline \multicolumn{1}{|c|}{ Enterprise } & \multicolumn{1}{c|}{ Regression equation } \\
\hline PrJSC Kharkiv Bearing Plant & $K R=-496.47 \cdot V D C+475.69 \cdot V E V-24565.1$ \\
\hline PrJSC "KhTZ" & $K R=642.15 \cdot V D C-573.18 \cdot V E V+129426.0$ \\
\hline PrJSC "Kharkiv Machine-Tool Plant" & $K R=31.08 \cdot V D C-2.01 \cdot V E V-10973.6$ \\
\hline Luhanskteplovoz PJSC & $K R=-282.66 \cdot V D C+16.17 \cdot V E V+200184.0$ \\
\hline PrJSC "AutoKrAZ" & $K R=-4976.45 \cdot V D C+5823.90 \cdot V E V-10^{6}$ \\
\hline Dniprovagonmash PrJSC & $K R=-1373.59 \cdot V D C+1149.96 \cdot V E V+72826.6$ \\
\hline
\end{tabular}

From the data in Table 7 it can be seen that, considering the enterprises under study, one of the components of fluctuations of the domestic currency has positive and the other negative values of the coefficients at independent variables. Therefore, we can conclude that the influence of fluctuations of the domestic currency on the volume of credits granted in the context of specific enterprises constantly has a negative component, despite the enterprise. Thus, when substantiating proposals to determine the expediency of attracting credit resources with a foreign currency component, this conclusion should be taken into account.

Table 8 presents regression equations with standardized coefficients at independent variables describing the influence of fluctuations of the domestic currency against the US dollar on the changes in the income received from the sale of products of the studied enterprises in terms of the volume of credits granted.
As can be seen from the data in Table 8, the regression equations with larger statistical estimates of significance reflect an insufficient effect of the volumes of credits granted on the changes in the obtained values in accordance with the negative influence of fluctuations of the domestic currency against the US dollar. This is due to the considerable dollarization of the Ukrainian economy, which, according to experts of the National Bank of Ukraine, fluctuates at $30 \%$. This conclusion should be taken into account when substantiating proposals to determine the expediency of attracting credit resources.

In general, these statistical generalizations contributed to the development of scientific and methodological approach to the analysis of the credit component of financial security. The approach takes into account time and currency determinants of credit resources in terms of stability of enterprise activity, which is determined with regard to the changes in sales and values of financial result.

Table 8

Regression equations to determine the influence of fluctuations of the domestic currency against the US dollar (VDC) on the changes in the income received (VD) from the sale of products of the studied enterprises together with the volume of credits granted (KR)

\begin{tabular}{|l|l|}
\hline \multicolumn{1}{|c|}{ Enterprise } & \multicolumn{1}{c|}{ Regression equation } \\
\hline PrJSC Kharkiv Bearing Plant & $V D=0.996 \cdot K R-0.060 \cdot V D C$ \\
\hline PrJSC "KhTZ" & $V D=-0.47 \cdot K R-0.65 \cdot V D C$ \\
\hline PrJSC "Kharkiv Machine-Tool Plant" & $V D=0.398 \cdot K R-0.760 \cdot V D C$ \\
\hline Luhanskteplovoz PJSC & $V D=0.151 \cdot K R+0.86 \cdot V D C$ \\
\hline PrJSC "AutoKrAZ" & $V D=0.774 \cdot K R-0.960 \cdot V D C$ \\
\hline Dniprovagonmash PrJSC & $V D=0.861 \cdot K R-0.730 \cdot V D C$ \\
\hline
\end{tabular}


Conclusions. The study of individual factors that influence the development of the credit component of the financial security of enterprises, which are generally divided into factors of the internal and external environment, helps substantiate the scientific and methodological approach to the analysis of using the credit component. The effectiveness of the internal environment factors that influence the development of the credit component of the financial security of enterprises is measured employing the totality of the indicators of creditworthiness, solvency, financial stability and financial status of an enterprise. This, along with the calculation of current assets to equity ratio provide for determining the possibility of using the credit component in activities of a particular enterprise. It is proved that the slowdown in the development of the credit component of financial security of the studied enterprises occurs due to excessive growth in their current liabilities compared to the relatively moderate changes in the volume of assets, limited possibilities of long-term borrowing, and low return on assets.

The consideration of fluctuations of the domestic currency as one of the key external factors influencing the development of the credit component of the financial security of the studied enterprises demonstrates that this factor negatively affects both the volume of borrowings and activities of the enterprise as a whole.

In general, the proposed approach to the analysis of statistical data, which can be used by enterprises to develop their financial security in terms of credit component, is designed to improve quality and promptness of management decisions based on accounting and auditing data.

\section{LITERATURE}

1. Інноваційний розвиток корпоративних фінансів: тенденції та перспективи : монографія / за заг. ред. О. Терещенка. Київ : КНЕУ, 2017. 495 c.

2. Азаренкова Г. М., Легостаєв Д. І., Жовнір В. І. Діагностика стану антикризового управління на підприємстві. Фінанси, облік і аудит. 2017. Вип. 1 (29). С. 7-19.

3. Буряк П. Ю. Интегрированные предпринимательские структуры: формирование, эффективность, потенциал : монография. Львов : Логос, 2007. 467 с.

4. Самородов Б. В., Азаренкова Г. М., Шкодіна І. В. Рекомендації щодо визначення стабільності процесу банківського кредитування. Бізнес Інформ. 2019. № 2. С. 367-374.

5. Чайка Т. Ю., Лошакова С. Є., Водоріз Я. С. Розрахунок коефіцієнтів ліквідності за балансом, урахування фінансових і виробничих особливостей підприємства під час здійснення коефіцієнтного аналізу ліквідності. Економіка і суспільство. 2018. Вип. 15. С. 900-908.

6. Офіційний сайт Агентства з розвитку інфраструктури фондового ринку України (SMIDA). URL: http://smida.gov.ua

7. Гриценко М. П. Фінансовий аналіз : навч. посіб. Бердянськ : БДПУ, 2012. 140 с.
8. Положення про визначення банками України розміру кредитного ризику за активними банківськими операціями : Постанова Правління Національного банку України від 30.06.2016 № 351. URL: https://zakon.rada.gov.ua/laws/show/ v0351500-16

9. Голуб Ю. О. Застосування процедури аналізу доцільності кредитування суб'єктів господарювання в аудиторській діяльності. Бізнес Інформ. 2012. № 8. С. 148-151.

10. Офіційний курс гривні щодо іноземних валют // Національний банк України. URL: https://bank.gov.ua/markets/ exchangerates

\section{REFERENCES}

Azarenkova, H. M., Lehostaiev, D. I., and Zhovnir, V. I. "Diahnostyka stanu antykryzovoho upravlinnia na pidpryiemstvi“ [Diagnosis of the State of Crisis Management at the Enterprise]. Finansy, oblik i audyt, no. 1(29) (2017): 7-19.

Buryak, P. Yu. Integrirovannyye predprinimatelskiye struktury: formirovaniye, effektivnost, potentsial [Integrated Business Structures: Formation, Efficiency, Potential]. Lvov: Logos, 2007.

Chaika, T. Yu., Loshakova, S. Ye., and Vodoriz, Ya. S. "Rozrakhunok koefitsiientiv likvidnosti za balansom, urakhuvannia finansovykh i vyrobnychykh osoblyvostei pidpryiemstva pid chas zdiisnennia koefitsiientnoho analizu likvidnosti" "Calculation of Liquidity Ratios on the Balance Sheet, Taking into Account the Financial and Production Characteristics of the Enterprise During the Ratio Analysis of Liquidity]. Ekonomika i suspilstvo, no. 15 (2018): 900-908.

Holub, Yu. O. "Zastosuvannia protsedury analizu dotsilnosti kredytuvannia subiektiv hospodariuvannia v audytorskii diialnosti" [Application of Procedure of Analysis of Crediting of Management Subjects in Public Accountant Activity]. Biznes Inform, no. 8 (2012): 148-151.

Hrytsenko, M. P. Finansovyi analiz [Financial Analysis]. Berdiansk: BDPU, 2012.

Innovatsiinyi rozvytok korporatyvnykh finansiv: tendentsii ta perspektyvy [Innovative Development of Corporate Finance: Trends and Prospects]. Kyiv: KNEU, 2017.

[Legal Act of Ukraine] (2016). https://zakon.rada.gov.ua/ laws/show/v0351500-16

"Ofitsiinyi kurs hryvni shchodo inozemnykh valiut" [The Official Exchange Rate of Hryvnia Against Foreign Currencies]. Natsionalnyi bank Ukrainy. https://bank.gov.ua/markets/exchangerates

Ofitsiinyi sait Ahentstva z rozvytku infrastruktury fondovoho rynku Ukrainy (SMIDA). http://smida.gov.ua

Samorodov, B. V., Azarenkova, H. M., and Shkodina, I. V. "Rekomendatsii shchodo vyznachennia stabilnosti protsesu bankivskoho kredytuvannia" [The Recommendations for Determining the Stability of the Process of Bank Crediting]. Biznes Inform, no. 2 (2019): 367-374.

Стаття надійшла до редакції 07.05.2020 p. 